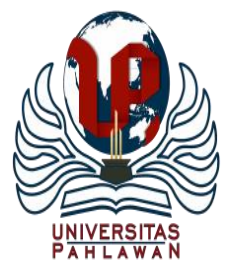

Edukatif : Jurnal Ilmu Pendidikan Volume 3 Nomor 4 Tahun 2021 Halm 2018 - 2026

EDUKATIF: JURNAL ILMU PENDIDIKAN

Research \& Learning in Education

https://edukatif.org/index.php/edukatif/index

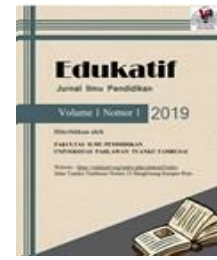

\title{
Pengaruh Pendekatan Pendidikan Matematika Realistik terhadap Sikap Positif Siswa
}

\author{
Dewi Purnama Sari ${ }^{1 凶}$, Azizah Yusra Amaliyah Harahap ${ }^{2}$, Agus Syahputra ${ }^{3}$ \\ Sekolah Tinggi Keguruan dan Ilmu Pendidikan Amal Bakti, Indonesia ${ }^{1,2,3}$ \\ E-mail : purnamasaridewi085@ gmail.com ${ }^{1}$, ayusraharahap@ gmail.com ${ }^{2}$, syahputraagus537@gmail.com ${ }^{3}$
}

\begin{abstract}
Abstrak
Penelitian ini merupakan penelitian eksperimen. Penelitian ini dilakukan di SMK PAB 2 Helvetia dengan sampel 40 siswa kelas XI. Penelitian ini bertujuan untuk melihat peningkatan sikap positif matematis siswa melalui Pendekatan Pendidikan Matematika Realistik (PMR) lebih baik dibandingkan siswa yang mengikuti pembelajaran konvensional. Pengukuran skala sikap positif terhadap matematika menggunakan model skala Likert yaitu skala sikap. Sikap matematis positif memiliki indikator, kepercayaan diri dalam matematika, kecemasan dalam matematika, penggunaan matematika, sikap menuju sukses, dorongan untuk sukses dalam matematika, persepsi sikap dan dorongan guru matematika. Rerata skala sikap positif siswa eksperimen dan kontrol adalah 62,40 dan 53,55. Hal ini menunjukkan bahwa sikap positif siswa pada kelas eksperimen lebih tinggi daripada sikap positif siswa pada kelas kontrol. Dari hasil penelitian diketahui bahwa terdapat peningkatan sikap positif matematis siswa melalui Pendekatan Pendidikan Matematika Realistik (PMR) lebih baik daripada siswa yang mengikuti pembelajaran konvensional.
\end{abstract}

Kata Kunci: : Pendekatan Pendidikan Matematika Realistik (PMR), Sikap Positif Siswa

\begin{abstract}
This research is an experimental research. This research was conducted at SMK PAB 2 Helvetia with a sample of 40 class XI students. This study aims to see an increase in students' positive mathematical attitudes by obtaining a better Realistic Mathematics Education Approach (PMR) than students who take conventional learning. Measurement of the scale of positive attitudes towards mathematics uses the Likert scale model of the attitude scale. Positive mathematical attitudes have indicators, confidence in mathematics, anxiety in mathematics, the use of mathematics, attitudes towards success, drive for success in mathematics, perceptions of attitudes and encouragement of mathematics teachers. The mean scale of the positive attitude of the experimental and control students was 62.40 and 53.55. This showed that the positive attitude of students in the experimental class was higher than the positive attitude of students in the control class. From the research results, it was found that there was an increase in students' positive mathematical attitudes by obtaining the Realistic Mathematics Education Approach (PMR) better than students who took conventional learning.
\end{abstract}

Keywords: Mathematics Learning Approach (PMR), positive attitude.

Copyright (c) 2021 Dewi Purnama Sari, Azizah Yusra Amaliyah Harahap, Agus Syahputra

$\triangle$ Corresponding author

Email : purnamasaridewi085@gmail.com

DOI : https://doi.org/10.31004/edukatif.v3i4.958

ISSN 2656-8063 (Media Cetak)

ISSN 2656-8071 (Media Online)

Edukatif : Jurnal Ilmu Pendidikan Vol 3 No 4 Tahun 2021 p-ISSN 2656-8063 e-ISSN 2656-8071 
2019 Pengaruh Pendekatan Pendidikan Matematika Realistik terhadap Sikap Positif Siswa - Dewi Purnama Sari, Azizah Yusra Amaliyah Harahap, Agus Syahputra

DOI: https://doi.org/10.31004/edukatif.v3i4.958

\section{PENDAHULUAN}

Pendidikan berlangsung di segala jenis, bentuk dan tingkat lingkungan hidup, yang kemudian mendorong pertumbuhan segala potensi yang ada di dalam diri individu sehingga menjadikan proses perubahan menuju pendewasaan, pencerdasan dan pematangan diri. Aspek psikologis yang turut memberikan kontribusi terhadap keberhasilan seseorang dalam menyelesaikan tugas dengan baik yaitu sikap. Sikap merupakan suatu kecendrungan seseorang untuk menerima atau menolak sesuatu konsep, kumpulan ide, atau kelompok individu. Matematika dapat diartikan sebagai suatu konsep atau ide abstrak yang penalarannya dilakukan secara deduktif aksiomatik. Hal ini dapat disikapi oleh siswa secara berbeda-beda, mungkin menerima dengan baik atau sebaliknnya. Dengan demikian sikap siswa terhadap matematika adalah kecenderungan untuk menerima atau menolak matematika. Sikap positif terhadap matematika berkolerasi positif dengan prestasi belajar matematika (Harahap \& Pratiwi, 2020).

Selain kemampuan kognitif aspek lain yang perlu diperhatikan adalah aspek afektif. Mengacu pada taksonomi bloom menurut Arikunto dalam Harahap keterampilan matematika meliputi domain kognitif, afektif dan psikomotorik. Harahap, Surya \& Syahputra (2018) Aspek psikologis yang turut memberikan kontribusi terhadap keberhasilan seseorang dalam menyelesaikan tugas dengan baik yaitu sikap. Sikap merupakan suatu kecendrungan seseorang untuk menerima atau menolak sesuatu konsep, kumpulan ide, atau kelompok individu. Matematika dapat diartikan sebagai suatu konsep atau ide abstrak yang penalarannya dilakukan secara deduktif aksiomatik. Hal ini dapat disikapi oleh siswa secara berbeda-beda, mungkin menerima dengan baik atau sebaliknnya. Dengan demikian sikap siswa terhadap matematika adalah kecenderungan untuk menerima atau menolak matematika. Sikap positif terhadap matematika berkolerasi positif dengan prestasi belajar matematika.

Sikap siswa terhadap matematika sangat erat kaitannya dengan minat siswa terhadap matematika, bahkan sebagian dari sikap merupakan akibat dari minat, misalnya siswa yang berminat terhadap matematika maka ia akan mengerjakan tugas matematika, ini pertanda bahwa siswa tersebut bersikap positif terhadap matematika. Dalam peraturan Menteri Pendidikan Nasional No 22 (Depdiknas, 2004) mengenai standar isi mata pelajaran matematika yang menyatakan bahwa tujuan nomor 5 pelajaran matematika di sekolah adalah supaya para siswa: "memiliki sikap menghargai kegunaan matematika dalam kehidupan, yaitu memiliki rasa ingin tahu, perhatian, dan minat dalam mempelajari matematika, serta ulet dan percaya diri dalam pemecahan masalah".

Berdasarkan pengamatan dan pengalaman penulis, banyak siswa yang mengatakan bahwa matematika itu sulit, rumit, membosankan, tidak menarik, dan tidak menyenangkan. Muhtadi dan Sukirwan (2017) menyatakan Matematika seringkali dikeluhkan peserta didik sebagai pelajaran yang sulit dan membosankan, karena matematika diajarkan dengan metode yang kurang menarik dan sulit dimengerti. Setelah penulis selidiki mengapa mereka beranggapan seperti tersebut di atas, ternyata penyebab utamanya adalah mereka tidak mengerti dan tidak memahami apa yang diinformasikan guru, kemudian pembelajaran yang diterapkan guru masih mengandalkan pembelajaran konvensional. Sehingga mereka benar-benar tidak memahami apa yang sedang dipelajari, yang pada akhirnya mereka beranggapan seperti di atas dan bersikap negatif terhadap matematika. Guru mendidik dan membimbing peserta didik agar kegiatan pendidikan terlaksana dengan baik. Guru yang profesional tidak hanya cukup memenuhi persyaratan administratif, melainkan bagaimana guru dapat memberikan pengertian, pemahaman, dan dapat mendorong peserta didik ke arah aktivitas secara individual terhadap ilmu yang diberikannya (Purba, Tumiyem, \& Sari, 2021). Secara tidak langsung, strategi yang dilakukan dengan tindakan yang tepat dapat mempengaruhi terhadap hasil belajar siswa. Proses pembelajaran yang efektif berbanding lurus dengan hasil yang didapatkan (Fauzan et al., dalam Suci, Taufina, 2020). 
2020 Pengaruh Pendekatan Pendidikan Matematika Realistik terhadap Sikap Positif Siswa - Dewi Purnama Sari, Azizah Yusra Amaliyah Harahap, Agus Syahputra

DOI: https://doi.org/10.31004/edukatif.v3i4.958

Dalam kegitan pembelajaran siswa adalah subjek dan mitra guru dalam mencapai tujuan pembelajaran. Oleh sebab itu kondisi siswa sangat menentukan keberhasilan pencapaian tujuan tersebut. Pengalaman menyenangkan dan tidak menyenangkan selama siswa belajar matematika akan membentuk sikap mereka terhadap pelajaran matematika dan hal ini akan terlihat pada perilaku mereka saat belajar matematika. Kualitas pembelajaran yang berhasil apabila dilihat dari segi proses yaitu apabila seluruhnya atau sebagian besar peserta didik terlibat secara aktif baik fisik, mental maupun sosial dalam proses pembelajaran di samping menunjukkan kegairahan belajar yang tinggi, semangat belajar yang besar dan percaya pada diri sendiri (Cahyadi, Widodo, Sari, 2021).

Pendekatan pembelajaran mempunyai andil yang cukup besar dalam kegiatan belajar mengajar. Kemampuan diharapkan dapat memiliki anak didik akan ditentukan oleh kerelevansian penggunaan suatu pendekatan pembelajaran yang sesuai dengan tujuan. Hal ini berarti tujuan pembelajaran akan dicapai dengan menggunakan pendekatan yang tepat, sesuai dengan standar keberhasilan terpatri di dalam suatu tujuan pendekatan yang digunakan dalam kegiatan pembelajaran bermacam-macam penggunaan tergantung dari rumusan tujuan. Untuk menumbuhkembangkan sikap positif matematika siswa diperlukan suatu pendekatan pembelajaran matematika yang mampu menumbuhkan sikap positif siswa. Salah satu pendekatan pembelajaran matematika yang dapat digunakan untuk mengembangkan kemampuan komunikasi dan sikap positif adalah pendekatan matematika realistik. Menurut Johanes (2018) agar kelas menjadi lebih baik maka diperlukan pengelolaan kelas yang baik pula. Pengelolaan kelas ini selain sebagai pendukung terjadinya gairah proses belajar dan pencapaian prestasi belajar yang tinggi, sekaligus dapat meningkatkan sikap positif disiplin pada siswa.

Pengelolaan kelas ini selain sebagai pendukung terjadinya gairah proses belajar dan pencapaian prestasi belajar yang tinggi, sekaligus dapat meningkatkan sikap positif disiplin pada siswa. Bandura dan Locke (dalam Sari \& Amran 2020) menjelaskan bahwa dalam kehidupan sehari-hari orang harus membuat keputusan untuk mencoba berbagai tindakan dan seberapa lama menghadapi kesulitan-kesulitan. Menurut Sinaga dalam Sari Seorang siswa yang memiliki sikap yang baik memiliki kepercayaan diri yang lebih baik sebagai hasilnya akan menumbuhkan rasa ingin tahunya dalam menyelesaikan soal matematika (Sari, Syahputra \& Surya, 2018)

Pendekatan Matematika Realistik (PMR) merupakan salah satu bentuk membelajarkan siswa dengan cara menyampaikan pengalaman langsung. Siswa belajar dari lingkungan yang ada disekitarnya. Pada pembelajaran ini, siswa dituntut untuk menemukan sendiri pengetahuan baru. Namun tidak hanya mendapatkan pengetahuan yang baru, lebih dari itu siswa diharapkan agar mampu memahami proses yang terjadi dalam mendapatkan ilmu itu. Dalam pembelajaran matematika realistik, titik mula pembelajaran haruslah nyata bagi siswa yang dapat mendorong siswa untuk terpaut dengan situasi tersebut (Wahyuni dan Jailani, 2017). Sedangkan guru dituntut untuk dapat memahami karakteristik belajar siswa, sehingga siswa dapat belajar dengan gayanya masing-masing, dengan begitu pembelajaran menjadi menyenangkan dan lebih bermakna, dan hal inilah yang akan menumbuhkan sikap positif siswa terhadap pembalajaran matematika. Menurut Ramadhani (dalam Sugianto, Roza, Maimunah 2020) pendekatan PMR menuntut siswa untuk mengontrakkan pengetahuan dengan kemampuannya sendiri melalui kegiatan yang dilakukan dalam kegiatan pembelajaran.

Pendidikan matematika realistis (RME) menurut Safitri, A., Surya, E., Syahputra, E., \& Simbolon (dalam Rajagukguk dan Hazrati, 2021) merupakan sebuah pendekatan yang berasal dari masalah kontekstual, dalam hal ini mahasiswa harus memiliki peran aktif dalam kegiatan pembelajaran, sedangkan guru berperan sebagai fasilitator. Penelitian Mauleto (2021) menyimpulkan bahwa dengan menggunakan desain pembelajaran dengan pendekatan pembelajaran matematika realistik seperti yang dilakukan pada penelitian ini yaitu peseta didik langsung terlibat aktif melakukan suatu aktivitas kegiatan yang secara nyata dan disesuaikan dengan dengan materi pelajaran dapat membuat siswa lebih mudah memahami materi dan juga karena 
2021 Pengaruh Pendekatan Pendidikan Matematika Realistik terhadap Sikap Positif Siswa - Dewi Purnama Sari, Azizah Yusra Amaliyah Harahap, Agus Syahputra

DOI: https://doi.org/10.31004/edukatif.v3i4.958

pembelajaran yang dilakukan berbeda dengan pembelajaran biasa sehingga membuat siswa lebih antusias dalam pembelajaran. Sejalan dengan penelitian Karmila dan Atiqoh (2021) menunjukkan bahwa kemampuan komunikasi matematis siswa yang menggunakan pendekatan matematika realistik lebih baik daripada kemampuan komunikasi matematis siswa yang tidak menggunakan pendekatan matematika realistik.

Pendekatan Matematika Realistik (PMR) ini akan membantu kelompok siswa yang bersikap negatif terhadap matematika dalam memahami konsep-konsep matematika, sehingga siswa mampu melihat bagaimana konsep-konsep tersebut saling berhubungan dengan kehidupan sehari-hari. Dengan demikian siswa kelompok ini dapat menghubungkan benda nyata, gambar dan diagram ke dalam ide matematika, baik menjelaskan ide, situasi dan relasi matematik dalam lisan maupun tulisan dengan kehidupan sehari-hari. Dari buku "Psikologi Pendidikan dengan Pendekatan Baru", sikap adalah gejala internal yang berdimensi efektif berupa kecenderungan untuk mereaksi atau merespon (response tendensy) dengan cara yang relatif tetap terhadap obyek orang, barang dan sebagainya, baik secara positif maupun negatif. Menurut pengertian di atas, maka sikap ini ada yang bersifat positif dan ada pula yang bersifat negatif. Sikap siswa yang positif, umpamanya kecenderungan ujung tindakannya adalah memperhatikan, mendekati, menyenangi, mengharapkan obyek tertentu dan menerima. Adapun sikap positif ini, mengharapkan sesuatu yang diingini sesuai dengan obyek yang ada dan ia tidak akan menolak, selalu menerima (Khuzaimah, Arief dan Wibowo, 2021).

Berdasarkan hasil penelitian menurut Rismawati dan Komala (2018) peningkatan kemampuan pemecahan masalah matematis siswa yang menggunakan pendekatan Pendidikan Matematika Realistik (PMR) lebih baik daripada kemampuan pemecahan masalah matematis siswa yang menggunakan pembelajaran biasa, dan sikap siswa terhadap pembelajaran dengan pendekatan Pendidikan Matematika Realistik (PMR) sebagian besar adalah positif. Beberapa faktor mempengaruhi sikap siswa terhadap sains diantaranya proses pembelajaran, karakteristik siswa dan penguasaan guru dalam proses pembelajaran (Rusni, Bahri, dan Ristiana, 2020). Peneliti perlu mengembangkan pembelajaran matematika dengan pendekatan realistik untuk peningkatan sikap positif siswa.

\section{METODE PENELITIAN}

Penelitian ini dikategorikan sebagai penelitian eksperimen. Penelitian ini dilaksanakan di SMK PAB 2 Helvetia Populasi penelitian ini adalah SMK PAB 2 Helvetia, Sampel dalam penelitian ini dipilih secara acak (cluster random sampling) untuk ditetapkan sebagai kelompok eksperimen dan kelompok kontol. Sampel penelitian yaitu kelas XI terdiri dari 40 orang. Pengukuran skala sikap positif terhadap matematika menggunakan skala sikap model skala Likert. Sikap positif matematik memiliki indikator, kepercayaan diri dalam matematika, kecemasan dalam matematika, kegunaan matematika, sikap terhadap keberhasilan, dorongan untuk keberhasilan dalam matematika, persepsi terhadap sikap dan dorongan guru matematika.

\section{HASIL DAN PEMBAHASAN PENELITIAN}

Hasil angket sikap positif matematis memberikan informasi tentang sikap siswa terhadap matematika yang dialaminya sebelum dan sesudah dilakukan proses pembelajaran, baik di kelas eksperimen maupun di kelas kontrol. Informasi tersebut berupa data hasil angket sebelum pembelajaran, angket setelah pembelajaran, dengan Ngain ternormalisasi (N-Gain) dihitung dengan bantuan program MicrosoftOffice Excel 2007.

\section{Deskripsi Hasil Sikap Positif Siswa Kelas Eksperimen}

Berikut ini disajikan hasil analisis data sikap positif siswa, data ini diperoleh dari hasil tes skala sikap positif siswa, baik sebelum (pretes) maupun sesudah pembelajaran (postes) serta N-Gainnya. Setelah 
2022 Pengaruh Pendekatan Pendidikan Matematika Realistik terhadap Sikap Positif Siswa - Dewi Purnama Sari, Azizah Yusra Amaliyah Harahap, Agus Syahputra

DOI: https://doi.org/10.31004/edukatif.v3i4.958

dilakukan hasil pengolahan data sikap positif siswa, diperoleh skor terendah ( $\chi_{\text {min }}$ ), skor tertinggi ( $\chi_{\text {maks }}$ ), skor rata-rata ( $\chi$ rata-rata $)$ dan standar deviasi (SD) untuk kelas eksperimen dan kontrol seperti tampak pada Tabel 1 berikut ini:

Tabel 1 Deskripsi Hasil Sikap positif Siswa Kelas Eksperimen

\begin{tabular}{llllll}
\hline $\begin{array}{l}\text { Kelas } \\
\text { Eksperimen }\end{array}$ & $\begin{array}{l}\text { Skor } \\
\text { Maksimal }\end{array}$ & $X_{\text {min }}$ & $X_{\text {maks }}$ & $X_{\text {rata-rata }}$ & SD \\
\hline Pretes & 80 & 33.98 & 46.94 & 41.00 & 3.66 \\
\hline Postes & 80 & 53.02 & 69.45 & 62.40 & 4.05 \\
\hline N-Gain & 1 & 0.22 & 0.48 & 0.36 & 0.06
\end{tabular}

Untuk dapat membandingkan data pretessikap positif siswa dari kedua kelompok (eksperimen dan kontrol) digambarkan dengan diagram batang yang dapat dilihat pada gambar 1 berikut

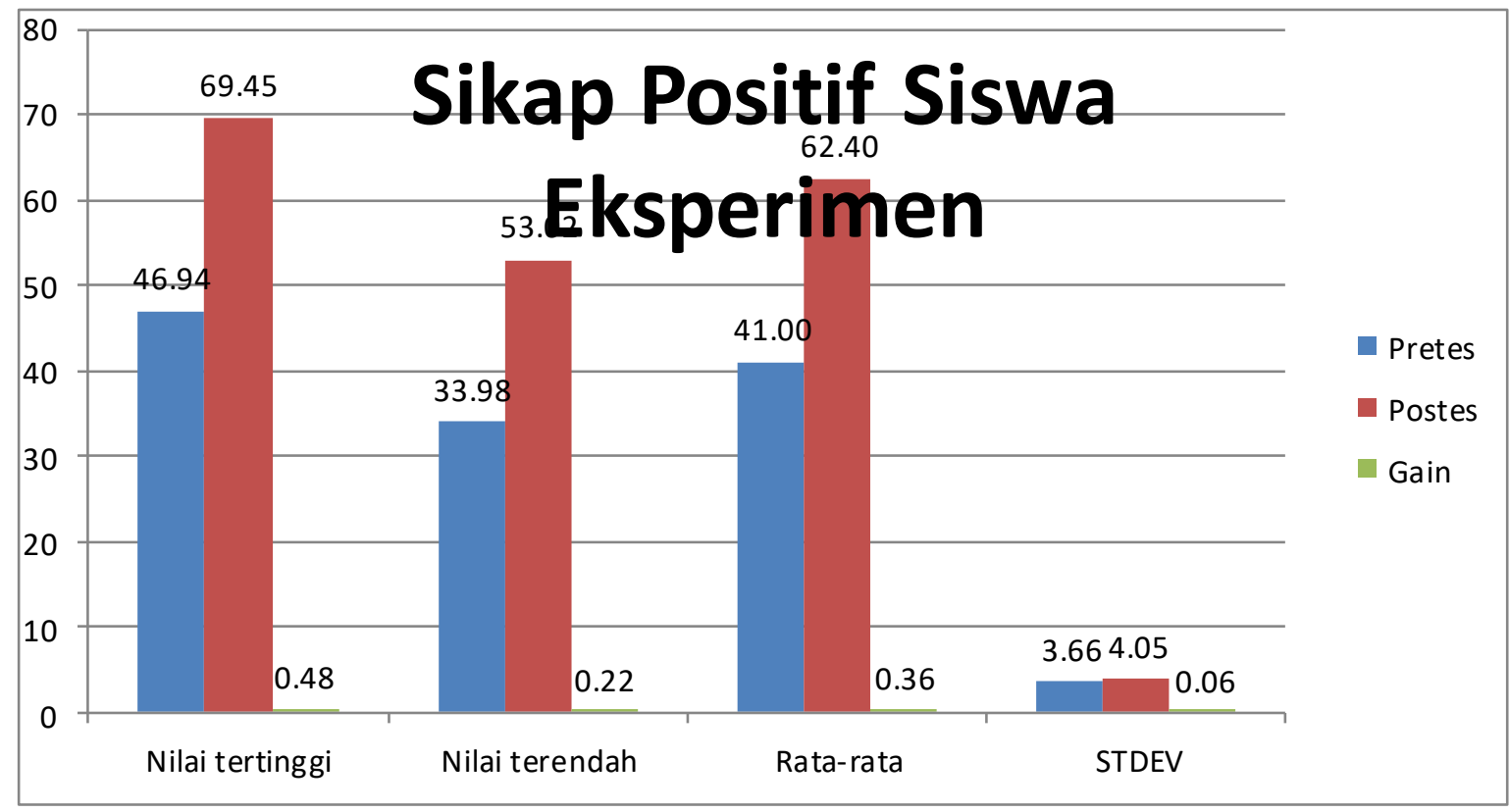

Gambar 1 Diagram Batang Skala Sikap Siswa Kelas Eksperimen

Dari tabel 1 dan gambar 1 dapat dilihat terdapat perbedaan sikap positif siswa di kelas eksperimen setelah pembelajaran diberikan. Hal ini memberikan gambaran terjadinya peningkatan, dengan skor rata-rata pretes 46.94 dan skor rata-rata postes 69.45, Standar deviasi pretes 3.66 dan Standar deviasi postes 4.05. Berdasarkan hal tersebut, dapat disimpulkan bahwa Sikap positif siswa di kelas eksperimen terdapat peningkatan setelah diberikan pembelajaran Matematika Realistik.

\section{Deskripsi Hasil Tes Sikap Positif Siswa Kelas Kontrol}

Setelah dilakukan hasil pengolahan data pretes, postes dan N-Gain sikap positif siswa, diperoleh skor terendah ( $\chi_{\text {min }}$ ), skor tertinggi ( $\chi_{\text {maks }}$ ), skor rata-rata ( $\left.\chi_{\text {rata-rata }}\right)$ dan standar deviasi (SD) untuk kelas kontrol seperti tampak pada Tabel 2 berikut ini:

Tabel 2 Deskripsi Hasil Tes Skala sikap siswa Kelas Kontrol

\begin{tabular}{llllll}
\hline Kelas Kontrol & $\begin{array}{l}\text { Skor } \\
\text { Maksimal }\end{array}$ & $\mathbf{X}_{\text {min }}$ & $\mathbf{X}_{\text {maks }}$ & $\mathbf{X}_{\text {rata-rata }}$ & SD \\
\hline Pretes & 80 & 32.24 & 45.52 & 40.00 & 3.66 \\
\hline Postes & 80 & 44.07 & 62.54 & 53.55 & 4.47 \\
\hline N-Gain & 1 & 0.01 & 0.37 & 0.22 & 0.07 \\
\hline
\end{tabular}


2023 Pengaruh Pendekatan Pendidikan Matematika Realistik terhadap Sikap Positif Siswa - Dewi Purnama Sari, Azizah Yusra Amaliyah Harahap, Agus Syahputra

DOI: https://doi.org/10.31004/edukatif.v3i4.958

Untuk dapat membandingkan data pretes, postes dan N-Gain sikap positif kelas eksperimen digambarkan dengan diagram batang yang dapat dilihat pada gambar 2 berikut:

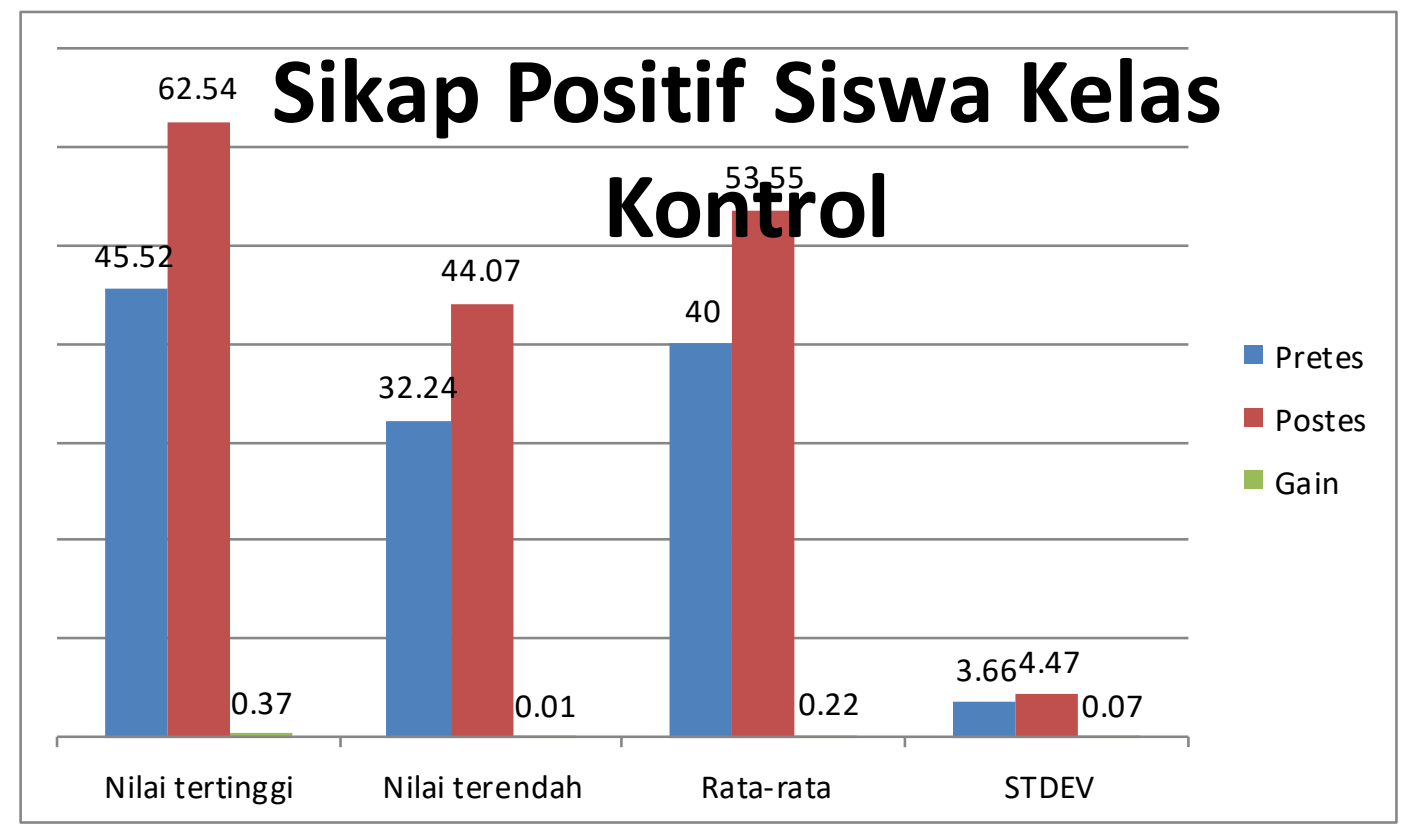

Gambar 2 Diagram Batang skala sikap siswa Kelas Kontrol

Dari tabel 2 dan gambar 2 dapat dilihat terdapat pebedaan sikap positif siswa di kelas kontrol setelah pembelajaran diberikan. Hal ini memberikan gambaran terjadinya peningkatan, dengan skor rata-rata pretes 45.52 dan skor rata-rata postes 62.23, standar deviasi pretes 3.66 dan standar deviasi postes 4.56. Berdasarkan hal tersebut, dapat disimpulkan bahwa skala sikap siswa di kelas eksperimen terdapat peningkatan setelah diberikan pembelajaran langsung.

\section{Deskripsi Hasil N-Gain Skala Sikap Siswa di Kelas Eksperimen dan Kelas Kontrol}

Untuk mengetahui peningkatan sikap positif siswa yang mengikuti pembelajaran matematika realistik dan siswa yang mengikuti pembelajaran langsung adalah dengan menghitung $\mathrm{N}$-Gain kedua kelas dengan menggunakan rumus $\mathrm{N}$-Gain ternormalisasi.Setelah dilakukan hasil pengolahan data $\mathrm{N}$ -

Gainsikap positif siswa, diperoleh skor terendah ( $\chi_{\min }$ ), skor tertinggi $\left(\chi_{\text {maks }}\right.$ ), skor rata-rata $\left(\chi_{\text {rata-rata }}\right.$ ) dan standar deviasi (SD) untuk kelas eksperimen dan kontrol seperti tampak pada Tabel 3 berikut ini

Tabel 3 Rataan N-Gain skala sikap Siswa di Kelas Eksperimen dan Kelas Kontrol

\begin{tabular}{llllll}
\hline Kelas & $\begin{array}{l}\text { Skor } \\
\text { Maksimal }\end{array}$ & $\mathbf{X}_{\text {min }}$ & $\mathbf{X}_{\text {maks }}$ & $X_{\text {rata-rata }}$ & STDEV \\
\hline Eksperimen & 1 & 0.22 & 0.48 & 0.36 & 0.06 \\
\hline Kontrol & 1 & 0.03 & 0.38 & 0.23 & 0.07 \\
\hline
\end{tabular}

Untuk dapat membandingkan data N-Gain sikap positif siswa kelas eksperimen dan kelas kontrol digambarkan dengan diagram batang yang dapat dilihat pada gambar 3 berikut: 
2024 Pengaruh Pendekatan Pendidikan Matematika Realistik terhadap Sikap Positif Siswa - Dewi Purnama Sari, Azizah Yusra Amaliyah Harahap, Agus Syahputra

DOI: https://doi.org/10.31004/edukatif.v3i4.958

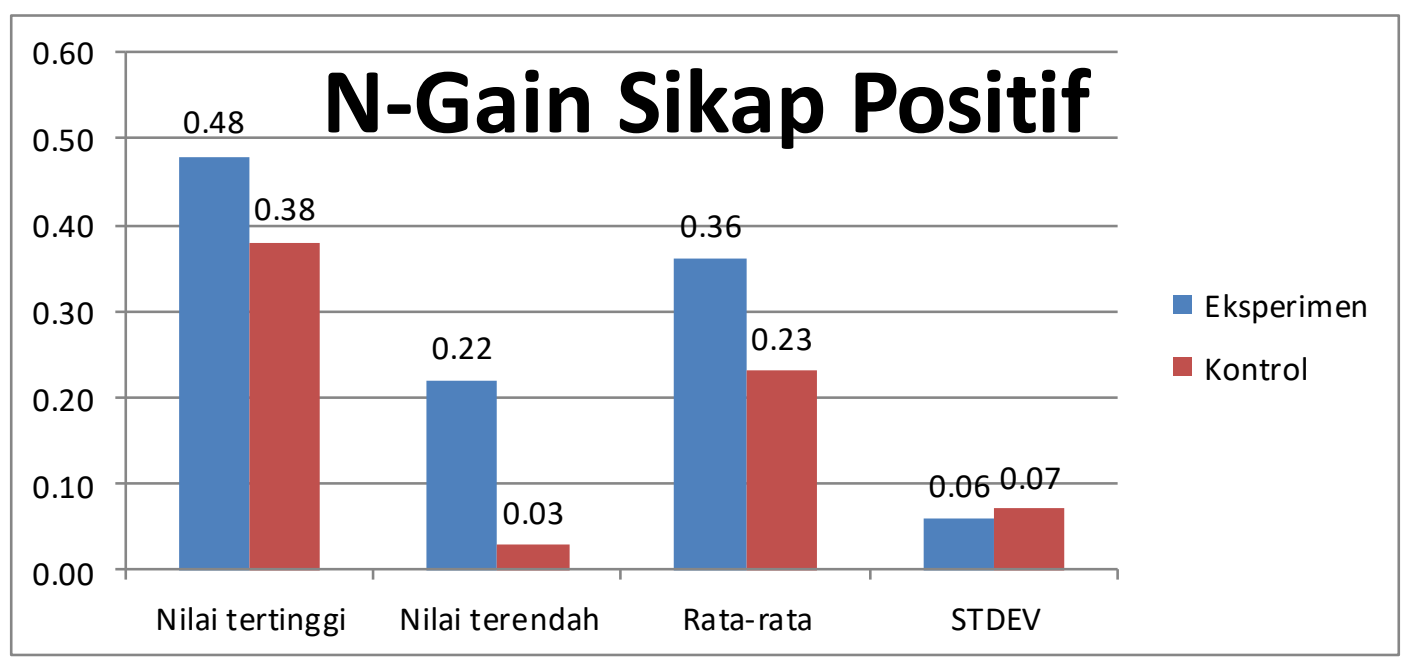

Gambar 3 Diagram Batang N-Gain SikapPositif Kelas Eksperimen dan Kelas Kontrol

Tabel 3 dan gambar 3 dapat dilihat terdapat perbedaan peningkatan sikap positif siswa dari kedua kelas. Skor Gain Tertinggi sikap positif siswa di kelas eksperimen (0.48) sedangkan di kelas kontrol (0.38). Apabila ditinjau dari nilai rata-rata skor gain, tabel ini juga memberi gambaran bahwa hasil N-Gain sikap positif siswa di kelas eksperimen lebih tinggi daripada sikap positif siswa di kelas kontrol, rata-rata skor gain di kelas eksperimen (0.36) sedangkan rata-rataskor gain di kelas kontrol (0.23). Standar deviasi di kelas eksperimen (0.06) dan standar deviasidi kelas kontrol (0.07). Hal ini memberikan gambaran sikap positif siswa di kelas eksperimen lebih tinggi daripada sikap positif siswa di kelas control.

\section{KESIMPULAN}

Dari hasil analisis dan pembahasan dalam penelitian ini, dapat disimpulkan, terdapat peningkatan sikap positif matematis siswa dengan memperoleh Pendekatan Pendidikan Matematika Realistik (PMR) lebih baik daripada siswa yang mengikuti Pembelajaran Konvensional. Penelitian Anwar (2017) menyatakan bagi siswa yang memiliki sikap positif terhadap suatu mata kuliah akan belajar sendiri dan mencurahkan perhatian penuh pada materi mata kuliah tersebut. Sebaliknya sikap siswa yang negatif tentang suatu mata pelajaran akan menyebabkan siswa tidak aktif dalam kegiatan pembelajaran dan pada akhirnya akan berpengaruh negatif pula pada mata pelajaran yang dipelajarinya. Perubahan sikap siswa cenderung lebih baik pada siswa yang berada pada kelas eksperimen. Berdasarkan pengukuran sikap siswa selama pembelajaran dengan penerapan pembelajaran konteksstual dapat diketahui bahwa perubahan sikap lebih baik pada kelas eksperimen (Andriyansyah, 2020).

\section{UCAPAN TERIMA KASIH}

Dalam kesempatan ini peneliti ingin mengucapkan terima kasih kepada: Ketua STKIP AMAL BAKTI yang telah memberikan perizinan. Kepala Sekolah SMK PAB 2 Helvetia dan Guru kelas IX yang telah memberikan izin dan membantu jalannya penelitian. Siswa kelas XI SMK PAB 2 HELVETIA yang telah antusias dalam menjalankan pembelajaran yang dilakukan peneliti. 
2025 Pengaruh Pendekatan Pendidikan Matematika Realistik terhadap Sikap Positif Siswa - Dewi Purnama Sari, Azizah Yusra Amaliyah Harahap, Agus Syahputra

DOI: https://doi.org/10.31004/edukatif.v3i4.958

\section{DAFTAR PUSTAKA}

Harahap, A, Y, A. Dan Pratiwi., A. 2020. Meningkatkan Kreativitas Matematika Siswa Dengan Strategi Inkuiri. Jurnal Tematik. Vol. 10. No.3. Hal. 151-159

Harahap, A. Y. A,. Surya, E Dan Syahputra, E. 2018. Differences Between Mathematics Representation Ability And Students Self-Efficacy By Using Learning Cycle 7E And Discovery Learning Based On Batak Angkola Culture In SMAN 1 Sipirok. American Journal Of Education Research. Vol. 6. No.11. Hal 1497-1504

Depdiknas. 2004. Standar Kompetensi Kurikulum 2004 Mata Pelajaran Matematika SMP Dan Mts. Jakarta: Puskur.

Muhtadi, D Dan Sukirwan. 2017. The Implementation Of Pendidikan Matematika Realistik (Pmr) Toimprove Mathematical Creative Thinking Ability And Selfregulated Learning Of Learners. Jurnal Mosharafa. Vol. 6 No. 1. Hal. 1-12

Johannes, N. 2018. Peningkatan Sikap Positif Disiplin Melalui Pengelolaan Kelasbagi Siswa Sd Negeri 41 Ambon. Jurnal Pedagogika Dan Dinamika Pendidikan. Vol. 6 No.1. Hal. 45-57

Sari, D.P Dan Amran. 2020. Pembelajaran Kooperatif Tipe Jigsaw Terhadap $\quad$ Keyakinan $\quad$ Diri (SelfEfficacy) Siswa. Al-Irsyad. Vol. 10. No. 213-222

Sari, D.P., Syahputra, E Dan Surya, E. 2018. An Analysis Of Spatial Ability And Self-Efficacy Of Students In Cooperative Learning By Using Jigsaw At Smas Muhammadiyah 8 Kisaran. American Journal Of Education Research. Vol. 6. No.8. Hal. 1238-1244

Wahyuni,N. D Dan Jailani, J. 2017. Pengaruh Pendekatan Matematika Realistik Terhadap Motivasi Dan Prestasi Belajar Siswa SD. Jurnal Prima Edukasia. Vol. 5. No.2 . Hal. 151-159

Andriansyah, E, H. 2020. Developing Positive Attitudes And Student Understanding Through Contextual Learning With Demonstration Methods Or Field Trip. PEDAGOGIA.Jurnal Pendidikan. Vol, 9 No. 1. Hal. 81-89

Anwar. C. 2014. Pencapaian Hasil Belajar Melalui Penumbuhan Sikap Mahasiswa. Lantanida Journal. Vol. 2. No. 2. Hal. 202-217

Purba. D. V, Tumiyem, \& Sari, D, P. 2021.Analisis Kesulitan Guru Pada Buku Tematikterpadu Jsit Kelas 3 Sd Al-Fityan School Kota Medan Tahun Pelajaran 2020/2021. Jurnal Pendidikan Dan Konseling. Hal. $154-148$

Rajagukguk, W. Dan Hazrati, K. 2021. Analisis Self-Efficacy Siswa Dalam Penelitian Pembelajaran Matematika Dengan Pendekatan Matematika Realistik Dan Inkuiri. Jurnal Cendekia: Jurnal Pendidikan Matematika. Vol. 5 , N0. 2, 2077-2089.

Mauleto, K. 2021. Dampak Pembelajaran Matematika Realistik Terhadap Kemampuan Pemecahan Masalah Matematis Siswa Dalam Materi Himpunan. Asimtot: Jurnal Kependidikan Matematika Vol, 3. No, 1, $21-33$.

Karmila, U Dan Atiqoh, K. S. N . 2021. Pendekatan Matematika Realistik Dan Kemampuan Komunikasi Matematis Siswa Di Madrasah Ibtidaiyah. Jurnal Padegogik. Vol 4, No. 1, 01 - 11

Khuzaimah, Arief, Z. A Dan Wibowo, S. 2021. Upaya Meningkatkan Sikap Positif Belajar Dan Kreativitas Anak Usia Dini Melalui Pembelajaran Problem Solving Di Ra Al Isro Bogor. Jurnal Teknologi Pendidikan. Vol. 10 No. 2, 88-106

Cahyadi, N. T,Widodo, H Dan Sari, D.P. 2021. Upaya Peningkatan Hasil Belajar Ppkn Melalui Penggunaan Media Pembelajaran Powerpoint Pada Siswa Kelas VI C SD Negeri 064025 Medan. Al- Irsyad :Jurnal Pendidikan Dan Konseling. 155-165

Sugianto, Yenita Roza, Maimunah. 2020. Mathematics Learning Media Development Using Realistic Mathematics Education. Journal Of Educational Sciences Vol. 4 No. 668-678 
2026 Pengaruh Pendekatan Pendidikan Matematika Realistik terhadap Sikap Positif Siswa - Dewi Purnama Sari, Azizah Yusra Amaliyah Harahap, Agus Syahputra

DOI: https://doi.org/10.31004/edukatif.v3i4.958

Suci, D.W Dan Taufina. 2020. Peningkatan Pembelajaran Matematika Melalui Strategi Berbasis Masalah Di Sekolah Dasar. Jurnal Basicedu Vol. 4, No. 2., 505 - 512.

Rismawati; Komala, Elsa. (2018). Penerapan Pendekatan Pendidikan Matematika Realistik Untuk Meningkatkan Kemampuan Pemecahan Masalah Matematis Siswa. Indonesia Mathematics Education, Volume 1, Nomor 2. 135.

Rusni, Bahri, A. Dan Ristiana, E. 2020. Profil Sikap Ilmiah Siswa Kelas IV SD Inpres Ana Gowa Dan SD Negeri Tombolo K. Jurnal Sainsmat. Vol. IX, No. 1. 82-90 